\title{
Penerapan Model Pembelajaran Group Investigation Dengan Metode Bimbingan Individu Dan Kelompok Guna Meningkatkan Prestasi Belajar Matematika Siswa
}

\author{
I Ketut Sudiarta ${ }^{1}$ \\ 1SMP Negeri 1 Selat, \\ Karangasem, Indonesia \\ email: ketutsudiarta09@gmail.com
}

\begin{abstract}
Abstrak
Penelitian ini dilaksanakan di SMP Negeri 1 Selat dengan tujuan untuk meningkatkan prestasi belajar Matematika siswa kelas IX D SMP Negeri 1 Selat melalui penerapan model pembelajaran Group Investigation dengan metode bimbingan individu dan kelompok. Subjek penelitian ini adalah siswa kelas IX D SMP Negeri 1 Selat yang berjumlah 23 orang, dalam mata pelajaran Matematika. Data tentang prestasi belajar siswa diperoleh dengan menggunakan metode tes dengan instrumanya yaitu berupa tes prestasi belajar. Data tersebut kemudian dianalisis dengan menggunakan teknik analisis deskriptif kuantitatif. Hasil penelitian ini adalah: penerapan model pembelajaran Group Investigation dengan metode bimbingan individu dan kelompok dapat meningkatkan prestasi belajar Matematika siswa kelas IX D pada semester II SMP Negeri 1 Selat tahun pelajaran 2018/2019. Skor rata-rata prestasi belajar siswa menunjukkan adanya peningkatan dari awal pembelajaran, ke siklus I, hingga ke siklus II. Ratarata kelas prestasi belajar pada awal pembelajaran hanya mencapai 69,56, siklus I meningkat menjadi 73,91 pada siklus II menjadi 81,73. Ketuntasan klaksikal awal hanya mencapai 21,73\%, pada siklus I meningkat menjadi $52,17 \%$ dan pada siklus II menjadi $91,30 \%$.
\end{abstract}

Kata Kunci: Model Pembelajaran Group Investigation, Metode Bimbingan Individu Dan Kelompok, Prestasi Belajar.

\begin{abstract}
This research was conducted at SMP Negeri 1 Selat with the aim of improving the mathematics learning achievement of grade IX D students of SMP Negeri 1 Selat through the application of the Group Investigation learning model with the individual and group guidance method. The subjects of this research were students of class IX D SMP Negeri 1 Selat according to 23 people, in Mathematics. Data on student achievement were obtained using the test method with the instrument in the form of learning achievement tests. The data is then analyzed using quantitative quantitative analysis techniques. The results of this study are: the application of the Group Investigation learning model with individual and group guidance methods that can improve Mathematics learning achievement of class IX D students in the second semester of SMP Negeri 1 Selat in the 2018/2019 academic year. The average score of student learning achievement shows an increase from the beginning of learning, to cycle I, to cycle II. The average class of learning achievement at the beginning of learning only reached 69.56, the first cycle increased to 73.91 in the second cycle to 81.73 . Initial classical completeness only reached $21.73 \%$, in the first cycle it increased to $52.17 \%$ and in the second cycle it was $91.30 \%$.
\end{abstract}

Keywords: Group Investigation Learning Model, Individual and Group Guidance Methods, Learning Achievement.

\section{Pendahuluan}

Keberhasilan proses pembelajaran lebih banyak ditentukan oleh kemampuan guru dalam mengelola proses pembelajaran tersebut. Kadang ada guru yang disebut pintar tetapi

\footnotetext{
${ }^{*}$ Corresponding author.

Received 03 Februari 2020; Accepted 31 July 2020; Available online 1 September 2020

(c) 2020 MPI. All Rights Reserved
} 
lemah dalam menyampaikan pengetahuan dan pemahaman yang ada dalam dirinya maka tentu proses pembelajaran tidak akan berhasil dengan baik. Kadang ada guru yang disebut tidak terlalu pintar tetapi dalam menyampaikan dan mengelola pembelajaran lebih kreatif dan memahami cara penyampaiannya bisa jadi menyebabkan proses pembelajaran akan berhasil dengan baik. Di antara keduanya tentu yang paling sesuai adalah memiliki kemampuan profesionalisme keguruan dan mampu menyampaikan dengan baik demi terciptanya proses dan tujuan pembelajaran yang diharapkan untuk mampu meningkatkan ketakwaan terhadap Tuhan Yang Maha Esa.

Pembelajaran yang dilakukan antara guru dan siswa hendaknya mengacu pada peningkatan aktivitas dan partisipasi siswa. Guru tidak hanya melakukan kegiatan penyampaian pengetahuan, keterampilan, dan sikap kepada siswa, akan tetapi guru diharapkan mampu membawa siswa untuk aktif dalam berbagai bentuk belajar, berupa belajar penemuan, belajar mandiri, belajar kelompok, belajar memecahkan masalah, dan sebagainya. Hasil belajar siswa selain dipengaruhi oleh metode pembelajaran juga dipengaruhi oleh partisipasi siswa. Jika siswa aktif dan berpartisipasi dalam pembelajaran, maka tidak hanya aspek prestasi saja yang diraihnya namun ada aspek lain yang diperoleh yaitu aspek afektif dan aspek sosial.

Untuk dapat membelajarkan siswa sesuai apa yang diharapkan, guru harus didukung dengan pengetahuan dan pemahaman standar yang mesti dikuasai sesuai metodik dan didaktik, agar dapat mengelola secara profesional mata pelajaran yang diampunya. Kompetensi pedagogik yang dimaksud menurut (Mulyasa, 2011) sekurang-kurangnya meliputi: a) pemahaman wawasan atau landasan kependidikan; b) pemahaman terhadap peserta didik; c) pengembangan kurikulum/silabus; d) perancangan pembelajaran; e) pelaksanaan pembelajaran yang mendidik dan dialogis; f) pemanfaatan teknologi pembelajaran; g) evaluasi hasil belajar; dan h) pengembangan peserta didik untuk mengaktualisasikan berbagai potens yang dimilikinya.

Wardani dan Julaeha (dalam Modul IDIK, 4307: 1-30) mempersyaratkan 7 keterampilan yang mesti dikuasai guru dalam melaksanakan pembelajaran, untuk dapat disebut professional yaitu: 1) keterampilan bertanya, 2) keterampilan memberi penguatan, 3) keterampilan mengadakan variasi, 4) keterampilan menjelaskan, 5) keterampilan membuka dan menutup pelajaran, 6) keterampilan membimbing diskusi, 7) keterampilan mengelola kelas. Keterampilan-keterampilan ini berhubung dengan kemampuan guru untuk menguasai dasar-dasar pengetahuan yang berhubungan dengan persiapan dan pelaksanaan proses pembelajaran yang akan memberikan dukungan terhadap cara berpikir siswa yang kreatif dan imajinatif.

Namun dilapangan masih banyak kelemahan guru di dalam melaksanakan proses pembelajaran. Guru hanya bercerita di kelas dengan deskripsi yang kurang jelas tentang materi pembelajaran. Guru kurang memberikan kesempatan kepada siswa untuk berkembang sesuai dengan kemampuannya. Pembelajaran selalu berpusat pada guru sehingga siswa menjadi fasif atau kurang aktif. Pada akhirnya siswa kurang termotivasi untuk belajar sehingga kecerdasan siswa tidak sesuai dengan apa yang diharapkan.

Menyadari permasalahan yang sedang dihadapi, untuk mendukung semua yang telah dijelaskan di atas. Guru selaku peneliti yang bertugas di SMP Negeri 1 Selat mencoba melakukan koreksi dan refleksi atas prestasi belajar awal siswa kelas IX D semester II tahun pelajaran 2018/2019 yang ditemukan pada saat observasi. Rata-rata nilai mata pelajaran Matematika siswa yang diperoleh hanya mencapai 69,56 dengan prosentase ketuntasan belajar sebesar $21,73 \%$. Nilai tersebut ternyata masih jauh dari Kriteria Ketuntasan Minimal (KKM) yang ditetapkan sekolah yaitu 73,00.

Untuk mengatasi persoalan tersebut maka akan dilakukan penelitian sebagai solusi dan memecahkan permasalahan. Untuk mengotimalkan prestasi belajar siswa, perlu diadakan situasi pembelajaran yang menyenangkan dan merangsang minat siswa untuk lebih antusias berperan aktif dalam proses pembelajaran. Untuk mengetahui perubahan ke arah yang lebih baik dipandang perlu dilakukan Penelitian. Pada penelitian ini model pembelajaran kooperatif Group Investigation. Vygotsky (dalam Asma ; 40) menekankan bahwa "children's cognitive development is promoted and enhanced trough they interactions with more advancet and 
capable individuals". Pada seting belajar kooperatif, siswa dihadapkan pada proses berpikir teman sebaya mereka. Model ini tidak hanya menciptakan belajar terbuka untuk seluruh siswa, sehingga terjadi interaksi yang baik antara sesama siswa dan juga antara guru dan siswa. Dengan menerapkan model ini diharapkan tujuan pembelajaran dapat tercapai optimal, yaitu khususnya pada mata pelajaran Matematika sesuai dengan standar ketuntasan minimal 75,00, karena dengan model pembelajaran kooperatif Group Investigation dengan berpegang teguh dengan paradigma pembelajaran kontruktivistik. Siswa dapat melakukan pembelajaran yang meraka inginkan dan tidak hanya didominasi oleh ceramah guru dengan melalui media audio visual yang membuat siswa sangat antusias dalam belajar.

Model Group Investigation dengan metode bimbingan individu dan kelompok dapat melatih siswa untuk menumbuhkan kemampuan berfikir mandiri. Keterlibatan siswa secara aktif dapat terlihat mulai dari tahap pertama sampai tahap akhir pembelajaran. Dalam model Group Investigation terdapat tiga konsep utama, yaitu: penelitian atau inquiri, pengetahuan atau knowledge, dan dinamika kelompok atau the dynamic of the learning group, (Winataputra, 2001:75). Penelitian disini adalah proses dinamika siswa memberikan respon terhadap masalah dan memecahkan masalah tersebut. Pengetahuan adalah pengalaman belajar yang diperoleh siswa baik secara langsung maupun tidak langsung. Sedangkan dinamika kelompok menunjukkan suasana yang menggambarkan sekelompok saling berinteraksi yang melibatkan berbagai ide dan pendapat serta saling bertukar pengalaman melaui proses saling beragumentasi. Hal ini juga dikukung oleh pendapat (Krismanto, 2003) yang memberikan penjelasan tentang investigasi, yaitu sebagai kegiatan pembelajaran yang memberikan kemungkinan siswa untuk mengembangkan pemahaman siswa melalui berbagai kegiatan dan hasil yang benar sesuai.

Berdasarkan pemaparan di atas, maka pada penelitian ini akan mengambil judul tentang Penerapan Model Pembelajaran Group Investigation Dengan Metode Bimbingan Individu Dan Kelompok Guna Meningkatkan Prestasi Belajar Matematika Siswa Kelas IX D Semester II SMP Negeri 1 Selat Tahun Pelajaran 2018/2019.

\section{Metode Penelitian}

Penelitian ini dilaksanakan di SMP Negeri 1 Selat yang beralamat di Jalan saraswati, No 17 Muncan, Karangasem. Penelitian yang dilakukan termasuk penelitian tindakan. Oleh karenanya, rancangan yang khusus untuk sebuah penelitian tindakan sangat diperlukan. Peningkatan diri untuk hal yang lebih baik ini dilakukan terus menerus sampai tujuan tercapai (Suharsimi et al., 2006).

Untuk penelitian ini penulis memilih rancangan penelitian tindakan yang disampaikan oleh (Arikunto, 2010) seperti terlihat pada gambar berikut. 


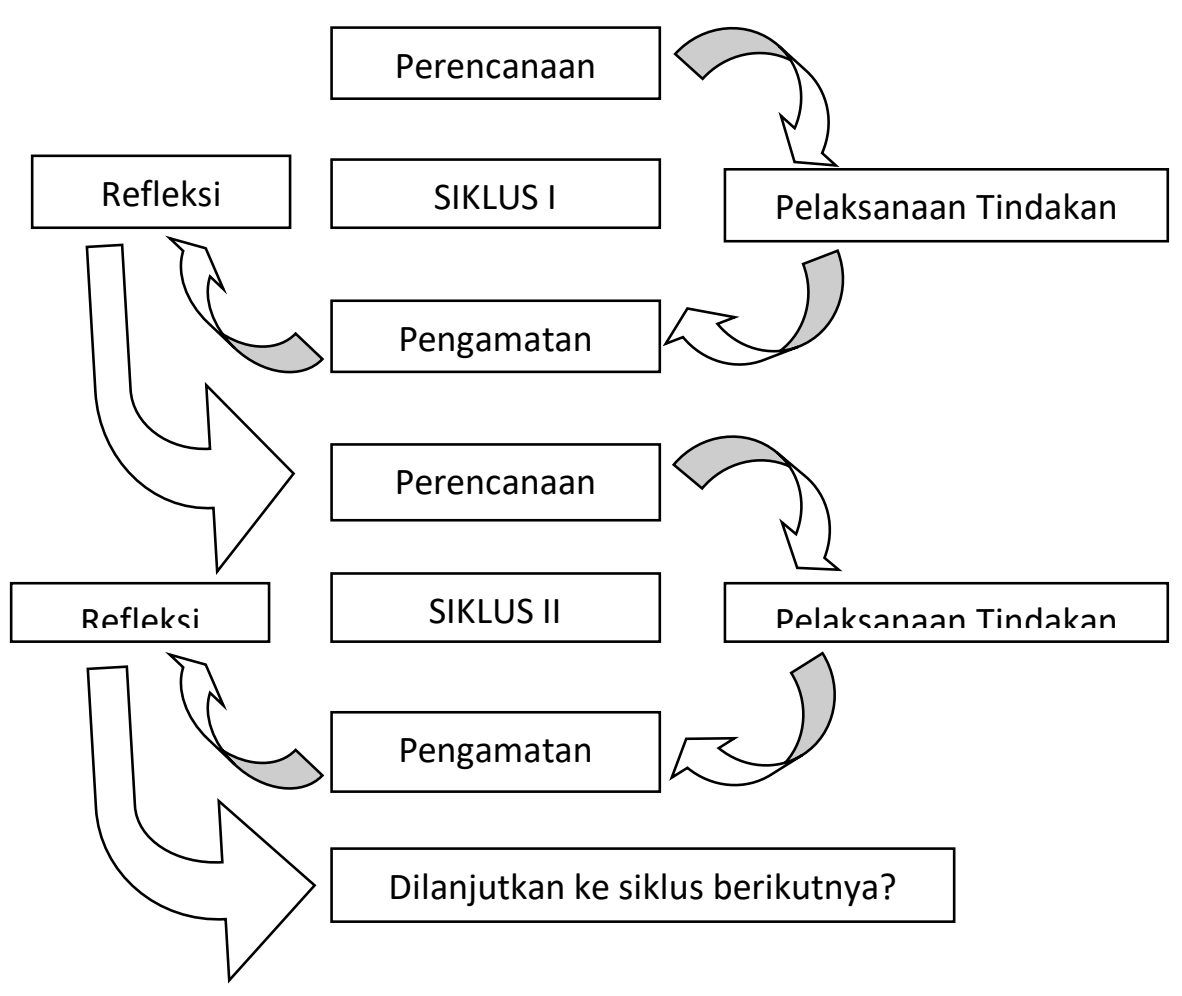

(Arikunto, 2010)

Gambar 01. Gambar Rancangan Penelitian Tindakan Kelas

Berdasarkan bagan, tahapan kegiatan penelitian dapat dijelaskan sebagai berikut:

\section{Siklus I}

1. Perencanaan Tindakan

Adapun perencanaan yang dilakukan untuk melaksanankan penelitian tindakan kelas adalah sebagai berikut.

1) Berkoordinasi dengan kepala sekolah untuk melaksanakan penelitian

2) Melakukan refleksi awal dengan melihat prestasi belajar Matematika siswa sebelum dilaksanakan penelitian.

3) Melakukan analisis kurikulum untuk mengetahui standar kompetensi, kompetensi dasar dan menyusun silabus yang disampaikan kepada siswa dengan menggunakan model pembelajaran Group Investigation dengan metode bimbingan individu dan kelompok.

4) Menyusun Rencana Pelaksanaan Pembelajaran (RPP) dilengkapi LKS yang dirancang. Langkah-langkah pembelajarannya diarahkan pada model pembelajaran Group Investigation dengan metode bimbingan individu dan kelompok untuk materi yang diajarkan.

5) Menyusun lembar penilaian dan tes/evaluasi berupa tes prestasi belajar dan kuesioner motivasi belajar.

6) Membuat ringkasan materi yang dibahas.

7) Membuat instrumen untuk penelitian tindakan kelas berupa lembar refleksi. 


\section{Pelaksanaan Tindakan}

Dalam pelaksanaan ini disusun sesuai dengan tahap pelaksanaan penerapan model pembelajaran Group Investigation dengan metode bimbingan individu dan kelompok dalam mata pelajaran Matematika untuk mengetahui prestasi belajar siswa. Pada setiap siklus penelitian terdiri dari 4 kali pertemuan. 3 kali pertemuan untuk melaksanakan proses pembelajaran dan 1 kali pertemuan untuk melaksanakan evaluasi atau tes prestasi belajar dan mengukur motivasi belajar siswa. Langkah-langkahnya adalah sebagai berikut.

1) Persiapan pada awal pembelajaran

Pada tahap ini, kegiatan yang dilaksanakan adalah mempersiapkan perangkat pembelajaran, membentuk kelompok learning komunity, menetukan skor awal, mengatur tempat duduk dan melakukan kegiatan apersepsi.

2) Pelaksanaan pembelajaran

Langkah-langkah dalam pelaksanaan tindakan ini adalah dilaksanakan sesuai dengan Rencana Pelaksanaan Pembelajaran (RPP) yang telah disusun dan disiapkan dengan menerapkan tahap-tahap model pembelajaran Group Investigation dengan metode bimbingan individu dan kelompok.

3. Observasi / Evaluasi

Pada pertemuan ke 4, guru melaksanakan tes prestasi belajar dan mengukur motivasi belajar siswa. Kegiatan yang dilakukan pada tahap evaluasi yaitu memberikan lembar tes evaluasi kepada siswa yang bertujuan untuk mengetahui prestasi belajar siswa dan kuesioner motivasi belajar untuk mengetahui tingkat motivasi belajar siswa setelah dilaksanakannya pembelajaran dengan model pembelajaran Group Investigation dengan metode bimbingan individu dan kelompok. Hasil evaluasi akan menjadi acuan bagi peneliti dalam merancang pembelajaran pada siklus berikutnya (siklus II).

4. Refleksi

Refleksi ini dilakukan untuk melihat dan mengkaji hasil tindakan pada siklus I mengenai prestasi belajar Matematika dan motivasi belajar siswa. Hasil kajian tindakan siklus I ini, selanjutnya dipikirkan untuk dicari dan ditetapkan beberapa alternatif tindakan baru yang diduga lebih efektif untuk meningkatkan prestasi belajar Matematika. Alternatif tindakan ini ditetapkan menjadi tindakan baru pada rencana tidakan dalam penelitian.

Metode yang digunakan untuk menganalisis data hasil penelitian ini adalah metode deskriptif. Untuk data kuantitatif dianalisis dengan mencari mean, median, modus, membuat interval kelas dan melakukan penyajian dalam bentuk tabel dan grafik.

Indikator keberhasilan penelitian yang diusulkan dalam penelitian ini pada siklus I dan siklus II mencapai nilai rata-rata minimal 74,00 dengan ketuntasan belajar minimal $85 \%$.

\section{Hasil Dan Pembahasan}

Penerapan penerapan model pembelajaran Group Investigation dengan metode bimbingan individu dan kelompok bertujuan untuk memberikan pembaruan pada kegiatan pembelajaran yang awalnya hanya didominasi oleh metode ceramah, tanya jawab, dan penugasan dan cenderung rutin dilaksanakan oleh guru. Pada pembelajaran konvensional tersebut siswa tidak mempunyai kesempatan untuk menyampaikan respon atas stimulus yang diberikan guru. Sebelum diterapkan model pembelajaran Group Investigation dengan metode bimbingan individu dan kelompok, terlebih dahulu dilakukan refleksi awal untuk mengetahui nilai prestasi belajar Matematika siswa Kelas IX D SMP Negeri 1 Selat semester II. Berdasarkan refleksi awal, prestasi belajar siswa berada pada kategori rendah, masih banyak siswa belum mencapai Kriteria Ketuntasan Minimal (KKM) yang ditetapkan sekolah yaitu 73.00. Rata-rata awal yang diperoleh hanya mencapai 69,56 dengan ketuntasan belajar $21,73 \%$. Hal ini terjadi karena pembelajaran yang berlangsung hanya bersifat konvensional. 
Sehingga siswa merasa bosan dan kesulitan dalam menerima pembelajaran. Oleh karena itu peneliti melakukan upaya untuk meningkatkan prestasi belajar siswa dengan mengubah sistem pembelajaran.

Harapan peneliti terkait prestasi belajar siswa belum terpenuhi pada siklus I walaupun model pembelajaran Group Investigation dengan metode bimbingan individu dan kelompok sudah diterapkan sesuai dengan skenario dan rancangan yang telah disusun. Hal ini dikarenakan adanya beberapa hal yang menjadi kendala dalam proses pembelajaran. Kendala-kendala pada siklus I meliputi: (1) Kegiatan awal pada proses pembelajaran belum optimal dalam menarik minat siswa serta kurang mengaitkan dengan topik yang akan dibahas. (2) pada fase mengidentifikasi topik siswa masih belum menunjukkan kemandirian dan kreatifitas dalam berpikir. (3) siswa kurang optimal dalam mengumpulkan informasi melalui sumber belajar yang tersedia. (4) siswa belum terbiasa membuat kesimpulan secara individu dan kurang berani menyampaikan hasil kerjanya.

Hasil refleksi pada siklus I dikaji dengan cermat sehingga dapat digunakan untuk mengoptimalkan hasil penelitian. Kendala-kendala pada siklus I dapat diatasi dengan bantuan dari berbagai pihak diantaranya: (1) Pada awal pembelajaran perhatian siswa ditarik tertarik dengan pertanyaan awal yang ditunjukkan guru. (2) Kemampuan siswa dalam mengidentifikasi topik dilatihkan dengan cara melibatkan peran serta guru dalam fase tersebut, sehingga siswa memiliki pentunjuk dalam mengembangkan pemikirannya. (3) Siswa diberikan keleluasaan untuk mempergunakan media ausio visual, guru berulang-ulang menampilkan media sesuai permintaan siswa. (4) Guru memberikan penjelasan pada siswa agar berani dan pecaya diri untuk menyampaikan hasil kerjanya. Guru membangun suasana belajar yang demokratis dan tetap terarah pada tujuan pembelajaran. Hal ini bertujuan agar siswa mampu mengembangkan pengetahuannya melalui unjuk argumen dengan rekannya, dan mengembangkan kemampuan berpikir tingkat tinggi.

Beberapa perbaikan pembelajaran yang dilakukan dapat meningkatkan prestasi belajar pengetahuan Matematika pada siklus I menjadi 73,91 yang tergolong pada kategori tinggi dan tingkat ketuntasan siswa secara klasikal sebesar 52,17\% Motivasi belajar siswa juga meningkat pada siklus II ketingkat 81,73 dengan ketuntasan belajar mencapai $91,30 \%$ dan tergolong pada kategori tinggi.

Berdasarkan hasil analisis tersebut dapat disimpulkan bahwa prestasi belajar Matematika siswa Kelas IX D SMP Negeri 1 Selat pada semester II tahun pelajaran 2018/2019 dapat ditingkatkan melalui penerapan model pembelajaran Group Investigation dengan metode bimbingan individu dan kelompok.

Hasil penelitian ini diperkuat juga dari hasil penelitan yang dilakukan oleh (Aliwu et al., 2016) dengan judul Penerapan Model Pembelajaran Kooperatif Tipe Group Investigasi Untuk Meningkatkan Aktivitas Dan Hasil Belajar Siswa Kelas VI SDN No.1 Labuan Bajo. Dalam penelitiannya disimpulkan bahwa: Penerapan model pembelajaran koperatif tipe Gl dapat meningkatkan aktivitas belajar siswa pada mata pelajaran IPA di kelas VI SDN No. 1 Labuan Bajo, besaran nilai aktivitas siswa yang dicapai berkisar antara $64.6 \%$ sampai $87.2 \%$ atau dengan kriteria cukup sampai sangatbaik dan dapat meningkatkan hasil belajar siswa pada mata pelajaran IPA di kelas VI SDN No. 1 Labuan Bajo, dengan capaianDSK dan KBK masingmasing $81 \%$ dan $95 \%$. Sehingga dengan demikian target ketercapaian dinyatakan berhasil sesuai ketentuan.

Penelitian yang dilakukan oleh (Lestari, 2017) dengan judul Penerapan Pembelajaran Group Investigation untuk Meningkatkan Prestasi dan Keaktifan Siswa Materi Statistika. Hasil penelitian ini menunjukkan bahwa kinerja guru dan aktivitas siswa telah memenuhi indikator dengan pelaksanaan PTK selama 2 siklus, sedangkan hasil belajar siswa dan prosentase ketuntasan $100 \%$ tercapai dengan penerapan PTK selama 3 siklus. Jadi, Group Investigation direkomendasikan untuk diterapkan dalam pembelajaran matematika karena dapat meningkatkan prestasi dan keaktifan siswakhususnya pada pembelajaran statistika. 


\section{Simpulan}

Berdasarkan penelitian yang telah dilakukan, dapat disimpulkan bahwa: penerapan model pembelajaran Group Investigation dengan metode bimbingan individu dan kelompok dapat meningkatkan prestasi belajar Matematika siswa kelas IX D pada semester II SMP Negeri 1 Selat tahun pelajaran 2018/2019. Skor rata-rata prestasi belajar siswa menunjukkan adanya peningkatan dari awal pembelajaran, ke siklus I, hingga ke siklus II. Rata-rata kelas prestasi belajar pada awal pembelajaran hanya mencapai 69,56, siklus I meningkat menjadi 73,91 pada siklus II menjadi 81,73. Ketuntasan klaksikal awal hanya mencapai 21,73\%, pada siklus I meningkat menjadi 52,17\% dan pada siklus II menjadi $91,30 \%$

\section{Daftar Pustaka}

Aliwu, Yupin, dkk. 2016. Penerapan Model Pembelajaran Kooperatif Tipe Group Investigasi Untuk Meningkatkan Aktivitas Dan Hasil Belajar Siswa Kelas VI SDN No.1 Labuan Bajo. e-Jurnal Mitra Sains, Volume 4 Nomor 2, April 2016 hlm 46-53.

Arends, Richard I. 2004. Learning to Teach. Sixth Edition. New York: McGraw-Hill.

Asikin dan Pujiadi. 2008. Pengaruh Model Pembelajaran Matematika Group Investigation Berbantuan Cd Interaktif Terhadap Kemampuan Pemecahan Masalah Pada Siswa Kelas X SMA Negeri 1 Semarang. FMIPA Unnes. Lembaran IImu Kependidikan Jilid 37, NO. 1, Juni 2008.

Asma, Nur. 2006. Model Pembelajaran Kooperatif. Jakarta: Depdiknas.

Buchori, 2012. Pengaruh Model Pembelajaran Matematika Group Investigation Berbantuan Software GeogebraTerhadap Kemampuan Pemecahan Masalah Pada Siswa SMA. Artikel Hasil Penelitian. Fakultas Pendidikan Matematika Dan IImu Pengetahuan Alam. IKIP PGRI Semarang.

Dimyati \& Mudjiono. 1994. Belajar dan Pembelajaran. Jakarta: Direktorat Jenderal Pendidikan Tinggi.

Hasan, S. 2011. Model Cooperative Learning Tipe Group Investigation untuk Meningkatkan Hasil Belajar pada Mata Pelajaran Perawatan dan Perbaikan SistemRefrigasi. INVOTEC. Volume VII. No.2.pp.189-198.

Irwan, N., \& Sani, R. A. 2015. Efek Model Pembelajaran Kooperatif Tipe Group Investigation dan Teamwork Skills terhadap Hasil Belajar Fisika. Jurnal Pendidikan Fisika,4(1), 4148.

Lestari, Sri. 2017. Penerapan Pembelajaran Group Investigation untuk Meningkatkan Prestasi dan Keaktifan Siswa Materi Statistika. Journal of Mathematics Education IKIP Veteran Semarang Volume 1 Nomor 2.

Prihaswati, M. 2014. Keefektifan Buku Peserta Didik (BPD) Dengan Metode Group Investigation Berbasis Kontekstual Untuk Menunjang Pembelajaran Matematika Materi Segitiga SMP. JKPM, Pendidikan Matematika FMIPA Universitas Muhammadiyah Semarang. Volume 1 Nomor 1. ISSN : 2339-2444.

Rahman, B. 2009.Perbandingan Kemampuan Koneksi Matematik Siswa yang Pembelajarannya Menggunakan Model Group Investigation dengan Siswa yang Pembelajarannya Menggunakan Model Konvensional. Skripsi. FPMIPA UPI. Bandung. 